\title{
CLOSURE: AN APPROPRIATED TECHNIQUE IN MALAY ABSURD PLAYS
}

\section{(Pengakhiran Cerita: Suatu Teknik dalam Karya Teater Absurd Melayu)}

\author{
Mas Rynna Wati Ahmad \\ masrynna@ukm.edu.my
}

School of Malay Language, Literature and Culture Studies, Faculty of Social Sciences and Humanities, Universiti Kebangsaan Malaysia, 43600 Bangi, Selangor Darul Ehsan, Malaysia.

Tel.: + 603-89213636

\section{Abstract}

The period of experimental theatre in the 1970s had brought a significant change in the history of modern Malay theatre. The plays that were produced and staged during this era had been categorized as absurd plays as they contained strong tendencies towards the application of the absurd theatre techniques. The most significant features of Western absurd plays would be that the play would end the way it begins; this cycle emphasizes the meaninglessness of life portrayed by the absurd playwrights. However, the scenario in Malaysia is different. Sensitive to the social and religious background of the Malays, these playwrights made adjustments to the typical absurd techniques common practised in the West. As opposed an ambivalent and dark end of the plays, Malay absurd playwrights tend to present a sense of hope through the closures presented at the end of the plays. Hence the theatre scholar, Solehah (1990) termed this as theatre absurd "ala" Malaysia as a way to characterize the unique version of the plays. This paper intends to delve further into the method of closure used by the playwrights such as Dinsman in his play, It is Not a Suicide and the late Anuar Nor Arai's play, Vacuum. The closures in the two plays are perceived as bringing a ray of light for the Malay absurd plays from being dark and inappropriate in the history modern Malay theatre into today's popular eclectic mainstream that marked the end of the period of realistic plays. 
Keywords: absurd plays, closure technique, modern Malay drama, hope and realistic plays

\begin{abstract}
Abstrak
Zaman teater eksperimental pada tahun 1970-an telah membawa satu perubahan besar dalam perkembangan teater Melayu moden. Teater yang dihasilkan pada era ekperimental bersifat absurd kerana pendekatan dan percubaannya yang cenderung ke arah falsafah absurd dari Barat. Teknikyang paling ketara dalam teater berbentuk ini ialah pengakhiran cerita berlaku seperti permulaan cerita yang menunjukkan kehidupan yang tiada makna. Namun demikian, teknik ini didapati tiada dalam teater Melayu beraliran absurd. Bersesuaian dengan masyarakat tempatan yang masih lagi kukuh berpegang kepada agama dan budaya, beberapa penulis telah melakukan pengubahsuaian dalam penghasilan karya teater mereka. Berbanding dengan teknik biasa dari Barat, iaitu tiada pengakhiran kepada setiap konflik yang diutarakan, teater absurd tempatan telah melakukan sebaliknya. Teater absurd Melayu memberikan harapan kepada persoalan yang diletakkan dalam plot cerita. Oleh yang demikian menurut Solehah (1970) teater absurd "ala" Malaysia mempunyai bentuk dan kelas yang tersendiri. Makalah ini akan memfokuskan kaedah yang digunakan oleh dua penulis teater, iaitu Dinsman, dalam Bukan Bunuh Diri dan Vakuum karya allahyarham Anuar Nor Arai. Pengakhiran cerita yang diberikan oleh penulis ini memberikan harapan kepada teater absurd Melayu yang tidak mendukung unsur pesimis dan putus harapan. Bentuk baharu ini, menunjukkan berakhirlah zaman teater realistik dalam tradisi teater Melayu moden.
\end{abstract}

Kata kunci: teater absurd, teknik pengakhiran, teater Melayu Moden, harapan dan teater realistik

\title{
INTRODUCTION
}

The Malay theatre in Malaysia has been evolving through time. From "bangsawan" plays to contemporary plays, the Malay theatre production has experienced many changes under the winds of modernization in the country. The forms and contents of the modern Malay theatre change as Malay playwrights respond to the dynamic political and social milieu. From the period after the Second World War till the present day, there has been no definite theatrical form which dominated the local theatre productions. Theatre experts on local Malay theatre use the term modern Malay theatre to refer to all the plays that were written within the period of realism during the 1960s. It is believed that the realistic plays then marked the breakthrough 
in the history of local productions. Plays like Atap Genting Atap Rumbia (The Tiled Roof and the Thatched Roof) and Tamu di Bukit Kenny (Visitors at Kenny Hill), are among the plays produced in the 60 s, which reflected the advancement in the local theatre trends.

When Bukan Lalang Ditiup Angin (It is Not The Grass that is Blown by The Wind) by Noordin Hassan was first staged in 1970, the play reflected the first transformation in modern Malay plays. The play which was first staged in Petaling Jaya Civic Centre shocked the audience. Throughout the play, the stage displayed no sitting room set. Noordin Hassan made a new transformation in which no other playwrights had done before. Many plays written by the later playwrights such as Johan Jaafar, Dinsman and Syed Alwi seemed to follow the trend of removing the sitting room as stage prop, and therefore, this marked a departure from realistic plays. A proper setting such as a sitting room set that was once believed to lie in the heart of realistic plays could no longer sustain its dominance in the local productions. The new experimental plays written by contemporary playwrights during the 1970s and 1980s marked a drastic change in the theatrical scene in this country. Many later productions benefited from these bold changes made in the techniques, styles and approaches in experimental plays. Nowadays, many new eclectic approaches have become prominent in the current local productions as the local theatre scene becomes more confident and breaks away from the conventional and the stereotypical theatre arts. This represents a positive approach towards the advancement of theatre as an art, which reflects the current social and political stability of the country. This is seen in Krishen Jit's opinion in an interview published in The Star, dated 23rd May (2003:3), "There is something about Malaysian plays. They are more textured and complex, as there is this reluctance to make things simple. There never has to be finality." Hence, there are new theatrical styles and approaches that later contribute to a more progressive development of Malay theatre productions.

\section{THE RISE OF THE THEATRE OF THE ABSURD IN MALAYSIA}

It is useful to trace the origins of absurd theatre. It was an anti-literary movement in the 20th century that was born and nurtured in Europe during the post-World War II era. Existentialist notions and impression of pessimisms, which rose after the terrible and horrifying war, led to this form of theatre. Some of the European playwrights questioned the truism of the so-called progress, civilization, and the reality of individuals in their plays. ${ }^{2}$ The 
influence of the theatre of the absurd is believed to have emerged in Malaysia after a devastating racial riot in the May 13th 1969 riot. $^{3}$

The influence of the theatre of the absurd on the Malay playwrights occurred very much later; especially in the early 1970s when the Malay playwrights were desperately looking for new approaches to the local theatrical production. Krishen Jit once mentioned "what distinguishes each play from the next and brings out a response from many playwrights in each generation, are the political events, which have shaped and scarred the country". ${ }^{4}$ Therefore, events such as May, 13th 1969 riot became a starting point for the restructuring of the society, especially the Malays. Solehah (1990) pointed out in her article, "Trends of Modern Malay Theatre" that, as a response to the riot, the government began to strengthen the acts and new ones were introduced. She emphasized that the change in political and social milieu had indeed brought a significant change to the modern Malay theatre in that period. She added that events such as May the 13th, resulted in a more earnest and serious response from the local playwrights. She further mentioned that it was the period that playwrights were more sensitive towards the changes inherent in the society. "The anger, hopelessness, turmoil and chaos prevalent in their society are reflected in the abstract plays of this decade as dramatists grope to find meaning and give direction to their shattered and splintered milieu" (1990:170). It can be said that theatre of the absurd had become an alternative medium to channel the playwrights' response, insights and feelings towards the social changes in the society at that time. The racial riot led to the requisitioning of national identity and purpose, which affected too many spheres of Malaysian life.

With regards to style, the playwrights of this era tend to experiment with new approaches in combination with traditional theatre techniques that not only reinforce the Malay culture but also to give the plays a dynamic contemporary meaning and image (Nur Nina, 1992: 145). It was during this time, that many playwrights had a strong tendency to experiment with the absurd theatre. The struggle within an individual's self had become one of the most experimented subject matter in these works, in which resembles a soul who was confused in the vortex of change in the new society. Hence, absurd technique was deemed fit to portray the struggles within an individual who intended to seek his roots and identity as it contains strong allegorical elements. ${ }^{5}$ Therefore, the strong allegorical elements became a suitable mode for the playwrights to express their insights in their works. 
A closer look at the works that were produced by these playwrights of the 1970s, shows that their works give primary attention to individual existential or more accurately the plays presented psychological dilemmas experienced by most of the characters found in the plays (Nur Nina \& Rahmah, 1988:144). The plays that were written during this period reflect on the issues that are existential and commonly represented by individuals who are caught in self-conflict in finding the meaning of life. The playwrights highlighted the dilemmas and confusion in their works through the characters in the plays. The pain and confusion further reflect the playwrights' insights and their concerns over social issues which took place at that time (Mohd. Ramli, 1991:21-23). While the main priority of realistic plays is to represent realistic representation of theatre, absurd plays on the contrary highlight on the conflict in the individual's self, the insights for meaning and truths in life.

This paper tries to focus on the common techniques that these playwrights employed. The common absurd techniques applied would be repetitive and nonsensical words that is evident in the dialogues. I perceive that the experiment by many playwrights during this period is an attempt to produce something different in the concept of Malay absurd. However, it is found that the experimentations made by these playwrights are not widely accepted by the local theatre critics and the audience. This is mainly because the plays were alleged to be vague and difficult to be understood (Nur Nina, 1992:154). As a result, the absurd plays have created confusion among the audience, as they cannot comprehend the meaning that the playwrights intended to present.

The rise of the absurd theatre in the period of the experimental theatre has been identified as unfit for the Malay theatrical arena. Since the Malaysian society is still basically a religious society, therefore the Western influence on the absurd plays is seen to be negating religious values which contradict many Islamic values. This phenomenon is closely related to its absurd origins and its epistemology, which have then created much confusion among the audience and most local theatre critics. With the advent period of the Islamic revivalism in Malay theatre in the 1980s, this has eliminated the opportunity of the absurd plays to sustain its popularity in the Malay theatrical arena.

\section{THE MAJOR DEVELOPMENT AND SETBACKS OF MALAY ABSURD PLAYS IN THE HISTORY OF MODERN MALAY THEATRE}

The advent of the absurd movement resulted in the growth of many young and talented playwrights who celebrated the fame of this new movement 
which promises an alternative mode of expressionism to the arts and society. Absurd theatre has never been successfully accepted by many theatre activists and the local audience. Since the absurd plays originated from the theory of existentialist, the society refused to accept its influence in the local productions. The audience rejected the emergence of theatre of the absurd mainly because, it contradicted with the socio-cultural background of the society since the society still basically upholds its religious beliefs and traditions. As a result, theatre of the absurd had a short span of popularity in the local theatre scene (Nur Nina, 1992:154).

Absurd theatre has created ongoing doubts and criticisms, as this style is perceived to be vague and difficult to be comprehended by many. This has resulted in confusion among the audience as they fail to appreciate these works. Thus, to many theatre critics, they feel that absurd plays are unable to relate its significance to the audience. It is through Mohamad Amin Arshad who stated that, any forms of literary works which includes drama, should be able to communicate well with the society as literature works function as a medium to disseminate good values for the people at large (1992:105-15). With this perception, absurd works are believed to have no values for the benefit of the society. Furthermore, the society is not familiar with the idea of pessimism of future as what is presented by this theatre. The audience prefers to be in their own comfort zone to watch plays that they can really associate with. The society's mentalities are basically bound by their ethnicity, religion and cultural beliefs. Hence, theatre of the absurd is not feasible to be promoted as a creative presentation for the audience.

Theatre of the absurd is not suitable for Malaysian viewers who are perceived to be generally still upholding their religious beliefs; therefore absurd theatre is seen as negating the Islamic principles. Many theatre critics and scholars are in view that the absurd theatre is flawed by the Western atheistic existentialism, hence not many scholarly articles or research have been pursued especially to bring about the importance or the significance of these works to the development of modern Malay theatre. Kalam (2003) also viewed that absurd plays in Malaysia was not having clear direction since the philosophies that influence the styles had been found unstable and thus inappropriate (2003:135). It is the philosophy that stands on the idea that humans should not be bound by any religious principles and values since these will limit their action and the way they think. The worldview also completely accepts the meaningless of life and solely based on human's struggles to achieve an authentic human existence. Apparently, these basic principles 
of the epistemology of the absurd theatre have absolutely contradicted the basic principles of Islam, which is the official religion of this country. Even though the Malaysian society exists in the threshold of modernization, its people still adhered to religious and social values. The surge in Islamic consciousness resulted in many comments and critics of the contemporary practitioners who believe that proponents of the theatre of the absurd were ignorant because being Muslims themselves, their attempts seemed to be insensitive to the origins and the philosophy which became the foundation for this type of theatre (Siti Jasmina, 2005:31). The criticisms showed that absurd theatre received a lot of flak.

In a similar trajectory, experimental dramatists viewed the Western form of absurd theatre as no longer appropriate in the period of intensified efforts to promote Malay culture and language (Nur Nina, 1992:154). Although Malay absurd styles do have some aspects in common with the Western contemporary theatre, many new dramatists tend to create their own platform to introduce new ideas and styles to compensate the new theatrical production which represents the social and political scenarios in the country. As a result, experimental dramatists gave priority to sources of inspiration from their own backgrounds and imagination, thus leading the modern theatre to a distinctly Malaysian identity. In the article "Trends in Modern Malay Theatre", Solehah argued that "the absurd dramatic form further illustrates the absurdity that these young, highly educated Malay playwrights feel at their own inability and helplessness to make known the shortcomings dominant in their society"(1990:163). She also added that the absurd plays that are written by local playwrights are far more objective than the typical absurd plays that originated from the West. It must be stressed here that the "absurd" plays in Malaysia are called as such because they are not realistic plays and most of their works are difficult to understand as the writing is not based on solid, philosophical or cultural tradition. "Malaysian theatre scholars, rooted in the Western tradition are aware that Malaysian absurd plays are in a class of their own and have no connection to the Western absurd plays. In fact, these theatre scholars have resorted to using the term "absurd ala Malaysia" or "abstract plays" (Solehah, 1990:170). Her statement shed some light and hence cleared many doubts and confusion on the unique adaptation of Malay absurd plays. Henceforth the paper will continue to use the term theatre absurd "ala" Malaysia as suggested by Solehah. 


\section{CLOSURE AS AN APPROPRIATED TECHNIQUE IN MALAY ABSURD PLAYS}

This paper intends to highlight the playwright's unique appropriation in two famous plays during the reign of experimental theatre in Malaysia. The plays are namely, It is Not a Suicide by Dinsman and Vacuum by the late Anuar Nor Arai. Theatre of the absurd's focus on the sense of meaninglessness of life, "caused by modern humanity's separation from their previous philosophical and theological certitudes" (Mostafa, 2005:87), have contributed to skepticisms among the local audience and theatre critics.

In relation to this, looking closely at the plays that were produced during the period of experimental theatre, it is found that most absurd works are not as simple as it might seem or even as absurd as it was once labeled. The plays are indeed philosophical. Mohd. Ramli mentions that in accordance with some sociological issues raised by the playwrights, the characters displayed in the absurd plays are actually searching for human dignity in the essence of life (1991:21-23). Therefore, it will be deemed inappropriate to classify all plays with elements of absurd theatre as being atheistic and pessimistic. The concept of Malay absurd is still left unrevealed by many. With the experimentation on some of the absurd theatre techniques these plays were soon to be termed as absurd and atheistic plays. However, not many critics or theatre experts tend to focus on the appropriation techniques applied by these playwrights to ensure their works are socially and religiously oriented. Many critics have indeed overlooked the final part of these plays. The finales contain hopes. Critics and even audience should be able to see through these works beyond the vague presentations. The closure provides a new path for the betterment of the characters for the future.

It is highlighted that Dinsman and Anuar Nor Arai experimentations on the absurd had further reflected strong philosophical underpinnings that highlight the deep emotional setbacks experienced by an individuals who are caught in the tumult of finding the right path. Even though their experimentations seem to be vague to many scholars and theatre critics, their mode of appropriation on absurd theatre technique had successfully transformed plays that were once known to be atheistic in nature to be distinctly in their class of their own. Unfortunately, their experimentation on absurd theatre was not clearly understood by many. This is because most theatre critics and local audience remain sceptical towards the fundamental philosophy of the absurd. As a result, the concept of Malay absurd in modern Malay theatre is still not fully received. Although the intellectual and religious maturity of the audience 
and the theatre scholars has grown over the years, the view of absurd works as pessimistic remains. Therefore this paper intends to offer more optimistic perspectives to the works of these two experimental playwrights.

It is argued that the play still functions within the Islamic parameters thus eliminating the atheistic label which clouded this work for more than three decades (Mas Rynna, 2013) ${ }^{6}$ only if the critics were able to pay more attention on closures offered in the two focused plays instead of labelling the plays as atheistic which was based on its epistemology of the philosophy underpinned the absurd theatre. This is simply because, Dinsman and Anuar Nor Arai tend to offer closure where the plays have proper endings with resolutions. Such divergence from any typical absurd plays have become the focal point of the discussion that needs to be studied further. With high awareness to the audience's social and religious background, such appropriations made possible by these two playwrights were deemed wise.

Experimental period is known to be the period whereby most playwrights were looking for a solid ground in expressing their insights. It was the period of confusions which also resembled the period of change of social milieu in the country at that time. The change of social and political policies strengthened by the local government created different reactions and these had been portrayed in the works of this period. Dinsman and Anuar Nor Arai were no exceptions. Both plays that become the main focus in this paper reflect that the two playwrights were trying to share their concerns for the society. Closures in both plays are not only as a mean to portray the major delineation from any typical absurd works found in the West but also it has become a solution to the matter raised by these two playwrights. The solutions have provided a ray of hope and life seems meaningful yet again.

Due to this change of perception, the Malay absurd plays can or cannot be termed absurd plays. The plays follow the common features of the absurd and the characters in each play reflect the clowning human attitudes whilst confronting conflicts. However, towards the ending of the plays, both plays represent a similarity that is; both plays have offered hope to every tumultuous experience felt by the characters in the plays. The provided solutions presented to the main characters that they are not alone and should not suffer from a prolonged unending anguish. With solutions that involve returning to basic Islamic tenets, the plays depart from the core characteristics of Western absurd plays. Therefore the term theatre of the absurd "ala" Malaysia that is suggested by Solehah in 1990 is the perfect choice to be applied here. It is a resemblance of an eclectic appropriation of plays to suit the local 
audience who are still strong in their religious background. Their method of appropriations on the theatrical techniques critically provides an avenue for young playwrights to continue experimenting with different eclectic approaches in bringing up the local concerns to become widely accepted.

\section{CLOSURE IN VACUUM BY ANUAR NOR ARAI}

The play, Vacuum, portrays a vague setting which resembles an ideal place for people who have stopped looking for the meaning of life. It is a place that makes people forget about spiritual fulfillment. The lifestyle that we can see in the play showed that the people always seek happiness through indulging themselves in their own fantasies. Secularism has taken place in the vacuum and this can be proven further as the Old Man, a character in the play, who keeps on saying that:

Old Man Don't go anywhere. Here is perfection personified, perfection of all those times. It is here that everything comes to an end. You don't have to search. You will not find what's not there.

(Vacuum, 1993:184)

The Old Man is saying that vacuum is a perfect place. On the contrary, we do know that there is no perfection above all in this life except God who is the most perfect. Therefore, the lines above indicate that the vacuum is a place that has no religious boundaries. People are free to do things they want, as spiritual fulfillment is the least of priority in the vacuum. The definition of happiness to the people is when they live freely and are happy with their lifestyle. The lines also indicate that the people who live in the vacuum will enjoy the lifestyle without having to worry about any religious or cultural sanctions that could bind their lives. The people should live the way they want, be happy with the way they see fit, but only that they have to stop looking for the meaning. Happiness is a package if one wants to live free without any forms of restrictions. From the lines too, it tells further that the vacuum privileges self- indulgence. This signifies that the happiness that is experienced by any souls who live in this vacuum is very superficial. This is simply because the happiness that is experienced by the people can be only fulfilled by achieving the desires in the present world. When everything in life is so detached from the spiritual or religious fulfillment, it seems to be based on self-desires. 
Vacuum is a play about the search for life perfection, and that is happiness in life. Unfortunately, many could not find the ways for their own happiness. The concept of happiness has always been perceived as achieving all the needs and desires present in the material world. From the Islamic perspective, it is true somehow that, humans must indeed find a balanced life; that is humans must be able to seek achievements and material wealth in order to survive in this present world. ${ }^{7}$ At the same time, the achievements and material wealth that are gained in this life shall not be gained through misguided means. Humans should remember that there will be an ultimate journey for them after death, and that is the ukhrawiyyah, which is the world hereafter. In this context, humans shall never forget that to achieve happiness in this world, humans must not forget to seek the blessings from God by pure submission and conscious together with obedience of God's commands and prohibitions. Therefore, in Islam, it is important to balance both dimensions of happiness, as a proper life in the present world will lead to a promised happiness in the next world.

When the vacuum offers too many good things for its people, slowly, people start to feel something is lacking in the spiritual aspects of their life. Not everyone is happy when everything is achieved. Human beings keep on looking for happiness in many forms, but to no avail, happiness still remains an abstract concept which leaves many to end up with dissatisfactions. In reality, they will continuously search for what they thought they miss, but not many come to the realization that they are simply lack in the spiritual aspect. In this play, Old Man cannot deny the needs of his people living in the vacuum just by providing all the material achievements. When he starts to force people not to look far beyond what is given in the vacuum, more people start to realize that they miss something in their life. In this case, in referring to the play, Young Man and Young Woman start to feel the void and they begin looking for what they need to find. They intend to look for things that they strongly believe should be there in their lives. Unfortunately, they know they could not find what they want as long as they are entrapped inside the vacuum, and therefore they need to escape from that crazy place.

Looking at the play, Old Man provides beautiful yet meaningless life to people who seek superficial happiness. Young Man believes he can find beyond what vacuum can offer him. He wants to find meaning. He wants to find happiness outside the vacuum. He believes that people in the vacuum live without religion. Their way of life is meaningless, hollow and unhappy. People are disillusioned with their own fantasies. They do not realize that they are trapped within their own thoughts and desires. This can be seen in the lines: 
Old Man But your fantasies become realities, right? See, see the vacuum that I've created so that this space is clean. In this vacuum we're prohibited from everything.

Young Man (Angrily). By hindering all that I want? There's nothing more true than the truth that's been created!

Old Man (He's angry. He walks about). Don't talk about that truth. Didn't we ignore it all these long while since we created this space?

Young Man (With raised voice). Our way of life is crazy and without religion. Show me the way out of this vacuum.

(Vaccum, 1993:192)

Here, it indicates that the Old Man is creating a vacuum, a place to be described as escapism. The Young Man understands perfectly well the disillusionment that the Old Man is trying to put up in that place. The Young Man has a choice to be happy in the unrealistic, unhappy, and meaningless world that vacuum would offer. On the contrary, he wants a realistic, substantial and meaningful happiness. Therefore, he can only find that outside the vacuum. He believes that happiness is not only what he should seek while living in this world. In this context, Young Man knows he can continue his life with a clear contention that his life is not his entirely. He must seek the way to gain what is to be achieved similar to a servant of God who seeks divine approval to live life ideally.

\section{CLOSURE IN IT IS NOT A SUICIDE BY DINSMAN}

When questions about the nature of existence and the purpose of life start to trouble the mind, the answers will not be found in the physical world as they can only be found in the spiritual world. Hence, the knowledge of self and the knowledge of God have become a foundation for humans to look further to grasp for meaning. This is the case with Adam in It is Not a Suicide. Adam's attempt to kill himself to meet God seems to be a genuine quest to fulfil his troubled mind and soul. Adam is portrayed to be a knowledgeable man, and the piles of books represent how much he has read in order to seek answers. However, the extensive knowledge has failed to provide him the answers that he yearns for. He craves for answers regarding his existence. Adam does not know himself anymore. He demands meaning to his life. He reads extensively, still his search seems to be futile. He mentions that: 
Adam: $\quad$ And I don't know for what I must live if I don't understand anything. For what do I live? What do I want to do with this empty life?

(It is Not a Suicide, 1988:155)

Adam feels that being religious has never helped him to find what he is looking for. The more he reads, the more he gets confused. Neither the book nor his faith helped him much to gain what he is looking for. $\mathrm{He}$ seems to be lost in his search. Any given comments or advice to him will be deemed useless. He persistently wants to fulfill his yearnings. This can be seen in the lines:

Adam: $\quad$ It's not I don't believe in religion, Father. It's not that I don't want to believe. Look! Look at this pile of books. Among all these books, not even one can answer my questions. (Adam listens to Father talking). For years I have been religious. Instead of questions being answered, more questioned have plagued me.

(It is Not a Suicide, 1988:155)

The confusion wraps him, since the more he reads, the more he gets upsets as he cannot find what he is looking for. The confusion has created a void, that only Adam can actually feel it. No one around seems to understand what are his yearnings and what has caused his pain. The entire setting reflects that Adam is alone. This can be seen through only two characters that Adam mentions in the play, Father-Who-Is-Unseen, who talks without voice, and Dewi, whose presence is indicated through her voice, not physical presence. $\mathrm{He}$ is alone in confronting his own fear and insecurity.

Adam is alone and the only way to get answers and fulfillment is through getting closer to God. Therefore, Adam's main search is to find God and he wants to ask Him about the meaning of his life. He knows God holds meaning, and he knows God's love is more fulfilling, but again he just does not know what else to do since everything he does in order to be closer to God seems futile. This can be seen in the lines:

Adam: $\quad$ Aah!! ....Don't disturb me. Thoughts that never give meaning. Emotions that never give meaning. I have obeyed you for a quarter of century. But you have never give me any meaning. (Jumps up. Walks wearily. Talks while pondering the noose) so many years I have waited for you. And you never, not even once, showed your countenance to me. (Talks from different place while reflecting upon the noose). So many years I have waited. and you never 
wanted to let me hear your voice. And I must still wait for you. Day after day after day. And I still remain like this, forced day after, after day to be here. And I must wait until... until when?

(It is Not a Suicide, 1988:153)

Adam knows he cannot wait anymore. He starts to become impatient.

Adam: Today, (holds the noose) today I will go to you. I will not commit suicide. This is my last attempt to meet you. There is only left for me to do.

Unfortunately, he does not perceive killing himself as a wrong thing to do since his main objective here is to meet God. Therefore, his reason justifies his action. Life has no meaning to him as he fails to find meaning.

Adam's search would relate to the situation whereby he tends to know God the way he wants it, through the concept that he knows of. Adam might have forgotten that to know God, he must know himself better, as this is the basic step to understand the purpose of living. Al-Ghazali mentioned that, knowing the self does not rely on looking to the outward self, meaning, recognizing the self as having shape, body, face, and senses. This is simply because such knowledge cannot compete with the knowledge of God. "Knowledge of this entity and its attributes which is the key to the knowledge of God" (The Alchemy of Happiness, 2007:4-5). Without it, man will never be revealed to the greatest gift ever given by God that is life itself. Adam fails to open his minds to look from another perspective. Since he fails to appreciate life as the basic fundamental for his real quest of finding meaning, by ending it, he demonstrates that life is not precious to him. But killing himself will not solve his problems but contributes to more meaningless solutions.

It is not easy to find what Adam is yearning for. To look forward to the meaning of life is like chasing for something elusive to the eyes, and the minds. However, it is worth to ponder and find the meaning of this life and strengthen the bond between God and self. This would be parallel with alGhazali's notion that since the heart holds the invisible truth of the meaning of life, the existence and the relationship between God and self, sometimes the truth can be elusive to find (The Alchemy of Happiness, 2007:4-5). Therefore, Adam is called to find it. Al-Ghazali also suggested that it is possible to comprehend the intangibles if humans intend to look further. To seek the reality of the heart, or the spirit, he suggested that humans close 
their eyes, and forget everything around them except their individuality. A person will then see the glimpses of the unending nature of that individuality (The Alchemy of Happiness, 2007:4-5). God cannot be found in the ray of light like most things in this world. Therefore, it is advisable that humans shall not find God through their eyes only. Humans will find the meaning of existence and comprehend the intangible bonds between humans and the Creator if they are able to see deep within their hearts.

Adam is an intelligent man who is gifted with intelligence and strongwilled in looking further for knowledge. What Adam needs is to look further into himself, understand his purpose to live in this world, before embarking on the next step in knowing God. The thorough knowledge of the spirit is not the necessary preliminary to walk in the path of religion, but comes rather as the result of self-discipline and perseverance in that path, as it is said in the Qur' an: "Those who strive in Our way, verily We will guide them to the right paths"(Surah al-Ankabut 29:69). The search will only strive along the perimeters of faith in God and Islam. This will circumvent the misunderstanding of the concept of God and existence so as not to let humans end up with further confusions.

Adam finds meaning of the existence; the existence of himself and the existence of God through logic minds. Unfortunately, his search is futile. He is unhappy, since he cannot find the meaning of his existence. This can be seen in the lines:

Dewi: $\quad$ Adam! You are not happy with my presence?

Adam: $\quad$ My presence. Not your presence. It is my presence that I question. Your presence is for yourself to question.

(It is Not a Suicide, 1988:165)

According to al-Ghazali, anyone who seeks happiness will realize that true happiness is necessarily linked with the knowledge of God. Each of the faculty of human delights was created by God. The highest function of all the souls is the perception of truth; in this accordingly it finds its special delight (The Alchemy of Happiness, 2007:33). Adam realizes this; therefore he seeks the ways which can make him closer to God. Unfortunately, his action to end his life is wrong. Adams' quest is indeed an honest search to seek for meaning. However, such knowledge cannot be found easily. The greatness of God immeasurably transcends our cognitive faculties, and we can only form a very dim and imperfect idea of it. Such imperfect knowledge is not a mere speculative knowledge, but must be accompanied by worship 
and devotion (The Alchemy of Happiness, 2007:35). Adam's devotion to worship God is a symbol that he truly believes that God holds meaning, this can be seen in the lines:

Adam: I have obeyed you for a quarter of century. But you have never given me meaning.

However, devotion to God is found to be insufficient. What Adam lacks here is the question of faith. He is questioning about the faith that he holds for a quarter of century. He wants to understand the meaning of his faith. Many who contemplate themselves to such notions have indeed failed. Al-Ghazali suggested that there are two ways to arrive at this knowledge. One that is so abstruse that it is not adopted to ordinary intelligence and therefore is better left unexplained. The other way is that when humans consider themselves, they realize that they have nothing, in a way that they were created by God, they would realize that they are helpless without the aid from God. From their wonders of bodily frame, to their various needs, they all come from God's power, wisdom and love to all His creations. In this way, the knowledge of oneself becomes a key to the knowledge of God. Not only are humans' attributes, but the mode of existence of humans' soul offers some insights into God's mode of existence (The Alchemy of Happiness, 2007:34-35). Adam has to realize that faith is a great gift from God that is yet to be achieved. By committing suicide, it will not fulfill what he is yearning for.

\section{CONCLUSION}

Anuar Nor Arai and Dinsman created plays that were heavy with the discussions of human existential issues. Hence, it is deemed impossible to depict the issues raised through typical realistic style in which realistic style had met its limitations. The absurd theatre style was considered fit to represent humans' psychological dilemmas into interesting visual representations for further reflections and discussions by the audience at large. Even though both playwrights' appropriations on absurd theatre style had attracted misleading criticisms, Vacuum and It is Not a Suicide are creative depictions of the playwrights' insights. It is very important to highlight here on Dinsman and Anuar Nor Arai's closures at the end of their focused plays. Pessimism is erased from It is Not a Suicide and Vacuum, hence it was then replaced by hopeful closures. Both playwrights suggested a return to the path of religion, 
which is Islam. Such a departure indicates that the Malay-Muslim worldview does not subscribe to a perpetual meaningless existence.

\section{ACKNOWLEDGEMENTS}

The author would like to express her gratitude to the Universiti Kebangsaan Malaysia for sponsoring this study under the research entitled, "Dramaturgical and Visual Arts Perspectives in Malay Absurd Theatre Performances" (Research Code: UKM GGPM-2012-039). This paper is an extension from previous $\mathrm{PhD}$ thesis that was later developed to become part of research funded by this grant. This paper was presented at ASEAUK (South- East Asian Studies) Conference, Brighton University 12th to 14th September 2014.

\section{NOTES}

1 Refer to the article by Lim Cheng Hoe, "Politics Play a Part” in The Star 23 May 2003.

2 Further discussion on history and origins of theatre of the absurd will be carried out in chapter 3 in Mas Rynna Wati Ahmad, 2011. "Western Existentialism in Selected Translated Malay Absurd Plays from an Islamic Perspective". PhD thesis, Universiti Putra Malaysia, Serdang, Malaysia.

3 Racial riots of May 13, 1969. Much has been written on this topic. Among others see Mahathir Mohamad, The Malay Dilemma (Singapore: Asia Pacific Press, 1979), Tunku Abdul Rahman, May 13th and After (Kuala Lumpur: Utusan Melayu Press, 1969), and National Operations Council, The May 13th Tragedy (Kuala Lumpur: National Operations Council, 1969) .

4 Refer to the article by Lim Cheng Hoe, "Politics Play a Part” in The Star 23 May 2003.

5 Abdul Rahman Napiah Interview via email dated December 1st 2009.

6 Mas Rynna Wati Ahmad, "Finding God in Dinsman's It is Not a Suicide: An Islamic Metaphysical Approach" in GEMA Online 13:3, pp. 223-35, 2013.

7 Refer to Syed Naquib al-Attas, 2001. Prolegomena to the Metaphysics of Islam: An Exposition of The Fundamental Elements of the Worldview of Islam. Kuala Lumpur : International Institute of Islamic Thought and Civilization (ISTAC).

\section{REFERENCES}

Afzalur Rahman, 1994. Al-Quran. Translated by Yusof Ismail. Kuala Lumpur: A.S Nordeen.

Al-Ghazali, 2007. Kimya a Saadat: The Alchemy of Happiness. Translated by Claude Field. Petaling Jaya.

Anuar Nor Arai, 1993. "Vacuum". Translated by Solehah Ishak in Modern Asean Plays Malaysia. Kuala Lumpur: Dewan Bahasa dan Pustaka. 
Dinsman, "It is Not a Suicide" Translated by Solehah Ishak in Malay Literature Journal 1:1, pp.151-81, 1988.

Esslin, M., 1968. The Theater of the Absurd. London: Pelican Books.

Kalam Hamidi, 2003. Pegangan Pementasan Drama. Bangi. Universiti Kebangsaan Malaysia.

Lim Cheng Hoe. "Politics Play a Part" in The Star, 23 May 2003.

Mas Rynna Wati Ahmad, 2011. "Western Existentialism in Selected Translated Malay Absurdplays from an Islamic Perspective". PhD thesis, Universiti Putra Malaysia, Serdang, Malaysia.

Mas Rynna Wati Ahmad, "Finding God in Dinsman's It is Not a Suicide: An Islamic Metaphysical Approach" in GEMA Online 13:3 pp. 223-35, 2013.

Mohd. Ramli, Raman. "Absurdisme dalam Drama melalui Analisis Karya Empat Penulis Kontemporari: Anuar Nor Arai, Johan Jaafar, Hatta Azad Khan dan Dinsman". Thesis Master of Arts. Universiti Malaya, 1991.

Mostafa Abedinifard, 2005. "Nihilism in Waiting for Godot". Unpublished MA thesis chapter, Allameh Tabataba'ee. University, Tehran, Iran.

Nur Nina Zuhrah, 1992. An Analysis of Modern Malay Drama. Shah Alam: BIROTEKS MARA Institute of Technology.

Rahmah, Bujang and Nur Nina Zuhrah, "It is Not a Suicide: A Malaysian Youth Dilemma" in Malay Literature 1:1, 1988.

Siti Jasmina Ibrahim, 2005. “Absurd Barat TiadaTuhan” in Utusan Malaysia, 27 March.

Solehah Ishak, "Trends of Modern Malay Theatre" in Malay Literature 3:2, pp. 162-72, 1990.

Solehah Ishak, 1992. Protest: Modern Malaysian Drama. Kuala Lumpur: Dewan Bahasa dan Pustaka.

Solehah Ishak, 1993. "General Introduction” in Zakaria Ariffin (ed.). Modern ASEAN Plays: Malaysia. Kuala Lumpur: Percetakan Season Sdn. Bhd.

Syed Muhammad Naquib al-Attas, 2001. "Prolegomena to the Metaphysics of Islam: An Exposition of The Fundamental Elements of the Worldview of Islam". Kuala Lumpur: International Institute of Islamic Thought and Civilization (ISTAC). Syed Naquib al-Attas, "Islamic Philosophy: An Introduction" in Journal of Islamic Philosoph. 1:2005, pp. 11-43, 1995.

Syed Naquib al-Attas, 1993. Islam and Secularism. Kuala Lumpur: International Institute of Islamic Thought and civilization (ISTAC). 